\title{
Analisis Faktor-Faktor yang Mempengaruhi Penerapan Berpikir Kritis Perawat dalam Melaksanakan Asuhan Keperawatan di Rumah Sakit
}

\author{
Yanti Sutriyanti ${ }^{1}$, Mulyadi ${ }^{2}$ \\ ${ }^{1,2}$ Prodi Keperawatan Curup, Poltekkes Kemenkes Bengkulu, Curup, Indonesia \\ iwanyanti70@gmail.com
}

\begin{abstract}
Critical thinking skills is a very essential ability in providing services to patients. Factors that can influence critical thinking skills include physical condition, motivation, anxiety, habits, intellectual development, consistency, feelings, and experience. These factors can provide positive support or can reduce critical thinking skills. The purpose of the study was to analyze the factors that influence the application of nurses' critical thinking skills in implementing nursing care to patients. Crossectional research design. The study population was inpatient nurses and a total population sample of 113 nurses. The results of this study (73\%) were female, (78\%) education was not Ners, (91\%) were married, (57\%) were civil servants, (53\%) were more than 30 years old, (58\%) were working long $<6$ years. There was a significant relationship between sex factors ( $p$. 005), duration of work ( $p$. 0,045), motivation ( $p$. 0.015), anxiety (p. 0.008), intellectual development ( $p$. 001), and experience (0.002) towards the application of critical thinking nurses in implementing nursing care. There was no significant relationship between factors of age, education, marital status, employment status, physical condition, feelings, habits, consistency in the application of nurse critical thinking in implementing nursing care ( $p$ value $>0.005$ ).The intellectual development of nurses can improve critical thinking which is the most dominant in implementing nursing care.
\end{abstract}

Keyword: Nursing care, Critical thinking, Nurses

\begin{abstract}
Abstrak
Kemampuan berpikir kritis merupakan kemampuan sangat esensial dalam memberikan pelayanan terhadap pasien. Faktor- faktor yang dapat mempengaruhi kemampuan berpikir kritis antara lain kondisi fisik, motivasi, kecemasan, kebiasaan, perkembangan intelektual, konsistensi, perasaan, dan pengalaman. Faktor tersebut dapat memberikan dukungan positif ataupun menurunkan kemampuan berpikir kritis. Tujuan penelitian ini menganalisis faktor yang mempengaruhi penerapan keterampilan berpikir kritis perawat dalam melaksanakan asuhan keperawatan. Desain penelitian crossectional. Populasi penelitian ini perawat ruang rawat inap, sampel sebanyak 113 perawat. Instrumen yang digunakan kuesioner sebanyak 32 item pernyataan. Analisis data menggunakan uji chi square dan uji pengaruh dengan regresi linier. Hasil penelitian di dapatkan responden $(73 \%)$ berjenis kelamin perempuan, $(78 \%)$ pendidikan bukan Ners, $(91 \%)$ sudah menikah, $(57 \%)$ pegawai Negeri Sipil, $(53 \%)$ usia lebih dari 30 tahun, (58\%) lama kerja $<6$ tahun. Ada hubungan yang bermakna antara faktor jenis kelamin $(\mathrm{p}=0.005)$, lama kerja $(\mathrm{p}=0.045)$, motivasi $(\mathrm{p}=0.015)$, kecemasan $(\mathrm{p}=0.008)$, perkembangan intelektual $(\mathrm{p}=0.001)$, dan pengalaman $(\mathrm{p}=0.002)$ terhadap penerapan berpikir kritis perawat dalam melaksanakan asuhan keperawatan. Tidak ada hubungan yang bermakna antara faktor usia, pendidikan, status perkawinan, status kepegawaian, kondisi fisik, perasaan, kebiasaan, konsistensi terhadap penerapan berpikir kritis perawat dalam melaksanakan asuhan keperawatan $(\mathrm{p}>0.005)$. Perkembangan intelektual perawat dapat meningkatkan berpikir kritis yang paling dominan dalam melaksanakan asuhan keperawatan.
\end{abstract}

Kata kunci: Asuhan keperawatan, berpikir kritis, perawat 


\section{PENDAHULUAN}

Kemampuan yang sangat esensial dan berfungsi dalam semua aspek kehidupan terutama dalam melaksanakan pekerjaan diperlukan kemampuan berpikir kritis agar masalah pekerjaan dapat diselesaikan dengan baik. Menurut Halpern (1996) berpikir kritis adalah suatu upaya yang dilakukan dalam memberdayakan keterampilan atau strategi kognitif untuk menentukan tujuan yang diharapkan. Oleh karena itu untuk memberikan perawatan yang aman dan efektif bagi pasien dengan kebutuhan yang kompleks sangat penting bagi perawat dapat mengembangkan keterampilan berfikir kritis (Kaddoura, 2010).

Kemampuan berpikir kritis perawat dibutuhkan juga dalam "transcultural nursing" yang merupakan asuhan keperawatan dengan area budaya keilmuan dalam proses pembelajaran dan praktek keperawatan focus memandang perbedaan dan kesamaannya antara budaya dengan asuhan keperawatan yang memerlukan penghargaan asuhan, sehat sakit, didasarkan pada nilai budaya manusia, kepercayaan dan tindakan, dan ilmu yang digunakan dalam melaksanakan asuhan keperawatan (Leininger, 2002).

Berbagai faktor yang bisa menyebabkan perbedaan dalam mengukur berpikir kritis antara hasil seseorang yang satu dengan yang lainnya menurut American Society of Registered Nurses (2007) adalah dijelaskan berpikir kritis dalam keperawatan sangat dipengaruhi oleh karakter psikologis, fisiologis, serta dapat dipengaruhi oleh lingkungan internal maupun eksternal seperti usia, tingkat kepercayaan, keterampilan, stress, dan kelelahan, serta rekan kerja. Sedangkan hasil penelitian lainnya dikatakan bahwa kemampuan berpikir kritis perawat dalam melaksanakan proses keperawatan tidak dipengaruhi oleh karakteristik individu seperti umur, jenis kelamin, pendidikan, dan pengalaman kerja serta status perkawinan (Sumartini, 2010). Sedangkan dijelaskan oleh lainnya bahwa factor salah satunya yang bisa menurunkan kemampuan berpikir kritis seseorang adalah terjebak dalam rutinitas, dan juga cara tersering yang membuat terjebak dalam rutinitas adalah membiasakan kita menggunakan model kebiasaan berlebihan (Rubenfeld \& Scheffer, 2007).

Faktor-faktor lainnya yang dapat juga mempengaruhi kemampuan seseorang dalam berpikir kritis adalah kondisi fisik seseorang, keyakinan diri/ motivasi, merasa kecemasan, kebiasaan atau rutinitas yang dikerjakan, perkembangan intelektual, konsistensi atau ketetapan, perasaan atau emosi, dan pengalaman yang biasa rutin dilakukan sewaktu bekerja (Rubenfeld \& Scheffer, 2007; Maryam, Setiawati, \& Ekasari, 2007). Berbagai faktor tersebut dapat berkontribusi memberikan pengaruhnya terhadap kemampuan berpikir kritis perawat disaat melaksanakan asuhan keperawatan dan juga dapat mempengaruhi kemampuan berpikir kritis perawat menurun disaat menghadapi pasien. Namun ini juga tergantung dari metode yang digunakan dalam mengukur kemampuan berpikir kritis perawat disaat melaksanakan asuhan keperawatan.

Survey yang dilaksanakan di rumah sakit masih ditemukan perawat dalam melaksanakan asuhan keperawatan hanya sebatas rutinitas kebiasaan yang belum mengembangkan keterampilan berpikir kritis. Hasil observasi dokumentasi asuhan keperawatan sebagai pencatatan pada critikal thingking dalam melaksanakan asuhan keperawatan mulai dari pengkajian sampai dengan evaluasi belum tergambar secara 
lengkap. Padahal rumah sakit telah mengembangkan sumber daya manusianya melalui pelatihan - pelatihan pengembangan ilmu keperawatan salah satunya adalah komunikasi therapeutik dalam keperawatan, penerapan keterampilan berpikir kritis bagi perawat dalam melaksanakan asuhan keperawatan.

\section{METODE}

Desain penelitian yang digunakan adalah desain penelitian korelasi. Pengambilan data cross sectional. Desain penelitian ini mempelajari hubungan faktor-faktor yang mempengaruhi penerapan berpikir kritis perawat dalam melaksanakan asuhan keperawatan di rumah sakit. Faktor-faktor tersebut meliputi kondisi fisik, motivasi, kecemasan, perkembangan intelektual, perasaan, kebiasaan / rutinitas, konsistensi, dan pengalaman perawat terhadap penerapan berpikir kritis perawat di rumah sakit.

Penelitian ini dilakukan mulai dari bulan Maret - November tahun 2018. Lokasi penelitian adalah Rumah Sakit Umum Daerah Curup. Data diambil dengan menggunakan instrumen pernyataan faktor-faktor yang dapat mempengaruhi berpikir kritis perawat meliputi pernyataan kondisi fisik 5 item, motivasi 5 item, kecemasan 5 item, perkembangan intelektual 5 item, perasaan 3 item, kebiasaan 3 item, konsistensi 3 item, pengalaman 3 item. Keseluruhannya 32 pernyataan. Setiap pernyataan diberi skor 1 4 selalu dilakukan (rutin) $=4$, sering dilakukan (banyak dilakukan tapi kadang ada yang tidak dilakukan) $=3$, kadang dilakukan (lebih banyak tidak dilakukan namun pernah melakukan) $=2$, tidak dilakukan $=1$. Uji reliabilitas instrumen dilakukan dengan membandingkan $\mathrm{r}$ alpha dengan $\mathrm{r}$ tabel.
Koefisien reliabilitas instrument sebesar 0.934. Populasi penelitian ini adalah perawat ruangan yang melaksanakan asuhan keperawatan pada pasien di ruang rawat di rumah sakit sebanyak 113 perawat. Sampel penelitian ini total populasi adalah seluruh perawat yang melaksanakan asuhan keperawatan pada pasien. Analisis data untuk melihat hubungan karakteristik responden serta faktor yang mempengaruhi berpikir kritis perawat (kondisi fisik, motivasi, kecemasan, perkembangan intelektual, perasaan, kebiasaan / rutinitas, konsistensi, dan pengalaman) dengan penerapan berpikir kritis perawat dalam asuhan keperawatan menggunakan uji statistik chi square. Sedangkan untuk mengetahui seberapa besar pengaruh karakteristik perawat dan faktor yang mempengaruhi berpikir kritis perawat terhadap penerapan dalam melaksanakan asuhan keperawatan menggunakan uji statistik regresi linier. Penelitian ini telah lolos kaji etik dengan No. DM.01.04/124/3/V/2018 dari komite etik Poltekkes Kemenkes Bengkulu.

\section{HASIL}

Tabel 1.Karakteristik Perawat Berdasarkan JK, Usia, Tk Pendidikan, Status Perkawinan, Status Kepegawaian, Lama Kerja di RSUD Curup Tahun 2018

\begin{tabular}{lcc}
\hline $\begin{array}{c}\text { Karakteristik } \\
\text { responden }\end{array}$ & Jumlah & Persentase \\
\hline Jenis kelamin & & \\
Laki-laki & 30 & 26.5 \\
Perempuan & 83 & 73.5 \\
Usia & & \\
Produktif & 53 & 46.9 \\
$\quad$ Non Produktif. & 60 & 53.1 \\
Tingkat pendidikan & & \\
Ners & 25 & 22.1 \\
D3/S1 Kep. & 88 & 77.9 \\
Status perkawinan & & \\
Belum nikah & 22 & 19.5 \\
$\quad$ Nikah & 91 & 80.5 \\
Status Kepegawaian & & \\
PNS & 49 & 43.4 \\
Kontrak & 64 & 56.6 \\
\hline
\end{tabular}




\begin{tabular}{ccc}
\hline Lama Kerja di RS & & \\
Lama & 47 & 41.6 \\
Belum lama & 66 & 58.4 \\
\hline
\end{tabular}

Tabel 1. menunjukkan bahwa jenis kelamin perawat yang melaksanakan asuhan keperawatan di ruang rawat inap rumah sakit sebagian besar perempuan (73.5\%), sebagian besar $(53.1 \%)$ usia produktif, sebagian kecil (22.1\%) mempunyai pendidikan ners, sebagian besar $(80.5 \%)$ sudah menikah, sebagian kecil (43.4\%) bekerja sebagai PNS, hampir sebagian $(41.6 \%)$ perawat sudah lama bekerja di rumah sakit.

Faktor-faktor yang mempengaruhi perawat berpikir kritis dalam melaksanakan asuhan keperawatan pada pasien di RSUD Curup sebagian kecil (35\%) mempunyai kondisi fisik yang baik, hampir sebagian (41\%) mempunyai motivasi yang tinggi, sebagian besar $(68 \%)$ melaksanakan asuhan keperawatan dalam kondisi tidak cemas, sebagian besar (61\%) mempunyai perkembangan intelektual yang baik.
Sebagian $(50.4 \%)$ mempunyai perasaan yang nyaman, sebagian besar (67 \%) sudah terbiasa berpikir kritis, sebagian besar (69\%) selalu konsisten, dan sebagian besar (60\%) berpengalaman berpikir kritis dalam melaksanakan asuhan keperawatan.

Penerapan berpikir kritis perawat dalam melaksanakan asuhan keperawatan pada pasien di RSUD Curup masih ditemukan sebagian kecil (31\%) kurang baik dalam melakukan pengkajian, sebagian kecil (34\%) kurang baik dalam menentukan diagnose keperawatan, sebagian kecil (26.5\%) kurang baik dalam merencanakan, sebagian kecil (26\%) kurang baik dalam melaksanakan tindakan, dan sebagian kecil $(36.3 \%)$ kurang baik dalam mengevaluasi asuhan keperawatan. Serta secara keseluruhan berpikir kritis dalam melaksanakan asuhan keperawatan sebagian besar (78\%) sudah baik penerapan berpikir kritis perawat dalam melaksanakan asuhan keperawatan.

Tabel 2. Hubungan Karakteristik perawat (Jenis Kelamin, Usia, pendidikan, Status perkawinan, Status kepegawaian, dan Lama bekerja sebagai perawat) dengan Penerapan Berpikir Kritis dalam Melaksanakan Askep di RSUD Curup Tahun 2018

\begin{tabular}{|c|c|c|c|c|c|c|c|c|}
\hline \multirow[t]{3}{*}{$\begin{array}{c}\text { Karakteristik } \\
\text { Perawat }\end{array}$} & \multicolumn{4}{|c|}{$\begin{array}{c}\text { PenerapanBerpikir Kritis } \\
\text { Dalam melaksanakan Askep }\end{array}$} & \multirow{2}{*}{\multicolumn{2}{|c|}{ Total }} & \multirow[t]{3}{*}{$\begin{array}{c}\mathrm{RR} \\
(95 \% \mathrm{CI})\end{array}$} & \multirow[t]{3}{*}{$\mathrm{P}$ value } \\
\hline & \multicolumn{2}{|c|}{ Baik } & \multicolumn{2}{|c|}{ Kurang Baik } & & & & \\
\hline & $\mathrm{n}$ & $\%$ & $\mathrm{n}$ & $\%$ & $\mathrm{n}$ & $\%$ & & \\
\hline \multicolumn{9}{|l|}{ Jenis Kelamin } \\
\hline Laki-laki & 23 & 76.7 & 7 & 23.3 & 30 & 100 & $0.87-1.42$ & 0.555 \\
\hline Perempuan & 57 & 68.7 & 26 & 31.1 & 83 & 100 & & \\
\hline \multicolumn{9}{|l|}{ Usia } \\
\hline Produktif & 33 & 62.3 & 20 & 37.7 & 53 & 100 & $0.62-1.09$ & 0.095 \\
\hline Non & 47 & 78.3 & 13 & 21.7 & 60 & 100 & & \\
\hline \multicolumn{9}{|l|}{ Produktif } \\
\hline \multicolumn{9}{|l|}{ Pendidikan } \\
\hline Ners & 18 & 75.0 & 6 & 25.0 & 24 & 100 & $0.82-1.40$ & 0.797 \\
\hline Bukan ners & 62 & 69.7 & 27 & 30.3 & 89 & 100 & & \\
\hline \multicolumn{9}{|l|}{ Status } \\
\hline \multicolumn{9}{|l|}{ Perkawinan } \\
\hline Belum nikah & 17 & 77.3 & 5 & 22.7 & 22 & 100 & $0.85-1.45$ & 0.629 \\
\hline $\begin{array}{l}\text { Sudah } \\
\text { menikah }\end{array}$ & 63 & 69.2 & 28 & 30.8 & 91 & 100 & & \\
\hline
\end{tabular}




\begin{tabular}{lllllllll}
\hline Status pegawai & & & & & & & & \\
$\quad$ PNS & 38 & 77.6 & 11 & 22.4 & 49 & 100 & $0.93-1.49$ & 0.241 \\
$\quad$ Non PNS & 42 & 65.6 & 22 & 34.4 & 64 & 100 & & \\
Lama Kerja & & & & & & & & \\
$\quad$ Sudah lama & 28 & 59.6 & 19 & 40.4 & 47 & 100 & $0.57-0.98$ & 0.045 \\
$\quad$ Belum lama & 52 & 78.8 & 14 & 21.2 & 66 & 100 & & \\
\hline
\end{tabular}

Tabel 2. Menunjukkan penerapan berpikir kritis perawat dalam melaksanakan asuhan keperawatan pada pasien dari hasil uji statistik chi square tidak ada hubungan yang signifikan antara jenis kelamin $p$ value 0.555 , usia $p$ value 0.095 , pendidikan $p$ value 0.797 , status perkawinan $p$ value 0.629 , status pegawai $p$ value $0.241>$ dengan penerapan berpikir kritis perawat dalam melaksanakan asuhan keperawatan pada pasien $p \alpha 0.05$. Sedangkan ada hubungan yang signifikan antara lama kerja perawat dengan penerapan berpikir kritis perawat dalam melaksanakan asuhan keperawatan pada pasien di RSUD Curup $p$ value 0.045 (CI ; 95\% 0.579-0.987)

Tabel 3. Hubungan Variabel Independen (Kondisi fisik, Motivasi, Kecemasan, Perkembangan Intelektual, Kebiasaan/ rutinitas, Perasaan) dengan Penerapan Berpikir Kritis dalam Melaksanakan Askep di RSUD Curup Tahun 2018

\begin{tabular}{|c|c|c|c|c|c|c|c|c|}
\hline \multirow{3}{*}{$\begin{array}{c}\text { Faktor yang } \\
\text { mempengaruhi } \\
\text { BPK }\end{array}$} & \multicolumn{4}{|c|}{$\begin{array}{c}\text { Penerapan BPK } \\
\text { dalam Askep }\end{array}$} & \multirow{2}{*}{\multicolumn{2}{|c|}{ Total }} & \multirow[t]{3}{*}{$\begin{array}{c}\mathrm{RR} \\
(95 \% \mathrm{CI})\end{array}$} & \multirow[t]{3}{*}{$\mathrm{P}$ value } \\
\hline & \multicolumn{2}{|c|}{ Baik } & \multicolumn{2}{|c|}{ Kurang Baik } & & & & \\
\hline & $\mathrm{n}$ & $\%$ & $\mathrm{n}$ & $\%$ & $\mathrm{~N}$ & $\%$ & & \\
\hline \multicolumn{9}{|l|}{ Kondisi Fisik } \\
\hline Baik & 33 & 82.5 & 7 & 17.5 & 40 & 100 & $1.01-6.71$ & 0.070 \\
\hline Kurang Baik & 47 & 64.4 & 26 & 35.6 & 73 & 100 & & \\
\hline \multicolumn{9}{|l|}{ Motivasi } \\
\hline Tinggi & 27 & 57.4 & 20 & 42.6 & 47 & 100 & $0.14-0.76$ & 0.015 \\
\hline Rendah & 53 & 80.3 & 13 & 19.7 & 66 & 100 & & \\
\hline \multicolumn{9}{|l|}{ Kecemasan } \\
\hline Tidak Cemas & 61 & 79.2 & 16 & 20.8 & 77 & 100 & $1.45-8.02$ & 0.008 \\
\hline Cemas & 19 & 52.8 & 17 & 47.2 & 36 & 100 & & \\
\hline \multicolumn{9}{|l|}{ Perkembangan } \\
\hline \multicolumn{9}{|l|}{ Intelektual } \\
\hline Baik & 57 & 82.6 & 12 & 17.4 & 69 & 100 & $1.83-10.2$ & 0.001 \\
\hline Kurang baik & 23 & 52.3 & 21 & 47.7 & 44 & 100 & & \\
\hline \multicolumn{9}{|l|}{ Perasaan } \\
\hline Nyaman & 44 & 77.2 & 13 & 22.8 & 57 & 100 & $0.82-4.29$ & 0.193 \\
\hline Kurang Nyaman & 36 & 64.3 & 20 & 35.7 & 56 & 100 & & \\
\hline \multicolumn{9}{|l|}{ Kebiasaan/Rutin } \\
\hline Sudah biasa & 50 & 65.8 & 26 & 34.2 & 76 & 100 & $0.17-1.16$ & 0.145 \\
\hline Kurang Biasa & 30 & 81.1 & 7 & 8.9 & 37 & 100 & & \\
\hline \multicolumn{9}{|l|}{ Konsistensi } \\
\hline Konsisten & 58 & 74.4 & 20 & 25.6 & 78 & 100 & $0.73-4.02$ & 0.308 \\
\hline Tidak konsisten & 22 & 62.9 & 13 & 37.1 & 35 & 100 & & \\
\hline \multicolumn{9}{|l|}{ Pengalaman } \\
\hline Berpengalaman & 56 & 82.4 & 12 & 17.6 & 68 & 100 & $1.73-9.60$ & 0.002 \\
\hline $\begin{array}{l}\text { Kurang } \\
\text { pengalaman }\end{array}$ & 24 & 53.3 & 21 & 46.7 & 45 & 100 & & \\
\hline
\end{tabular}


Tabel 3. Menunjukkan penerapan berpikir kritis perawat dalam melaksanakan asuhan keperawatan pada pasien di RSUD Curup, menggunakan uji statistik hubungan dengan uji chi square ditemukan pada motivasi $p$. value 0.015 , kecemasan p. value 0.008 , perkembangan intelektual p. value 0.001 , dan pengalaman $p$. value $0.002<$ dari p. $\alpha$ 0.05 yang artinya ada hubungan yang signifikan antara motivasi, kecemasan, perkembangan intelektual, dan pengalaman dengan penerapan berpikir kritis perawat dalam melaksanakan asuhan keperawatan di rumah sakit Curup. Sedangkan pada kondisi fisik p. value 0.070 , perasaan $p$. value 0.193 , kebiasaan $p$. value 0.145 dan konsistensi $p$. value 0.308 artinya tidak ada hubungan yang signifikan antara kondisi fisik, perasaan, kebiasaan, dan konsistensi dengan penerapan berpikir kritis perawat dalam melaksanakan asuhan keperawatan di Rumah Sakit Curup.

Tabel 4. Pemodelan Akhir Variabel Independen Faktor (Kondisi fisik, Motivasi, Kecemasan, Perkembangan Intelektual, Perasaan, Kebiasaan, Konsistensi, dan Pengalaman) dengan Penerapan Berpikir Kritis dalam Melaksanakan Asuhan Keperawatan di RSUD Curup Tahun 2018

\begin{tabular}{|c|c|c|c|c|c|c|c|}
\hline \multirow{2}{*}{$\begin{array}{l}\text { Variabel faktor } \\
\text { (Independen) }\end{array}$} & \multirow[t]{2}{*}{ B } & \multirow[t]{2}{*}{ Sig. } & \multirow[t]{2}{*}{ Exp.(B) } & \multirow[t]{2}{*}{$\mathrm{R}$} & \multirow{2}{*}{$\begin{array}{c}\mathrm{R} \\
\text { Square }\end{array}$} & \multicolumn{2}{|c|}{$95 \%$ CI for $\operatorname{Exp}(\mathrm{B})$} \\
\hline & & & & & & Lower & Upper \\
\hline Konstanta & 19.429 & & & 0.398 & 0.159 & & \\
\hline Motivasi & 0.902 & 0.062 & 0.406 & & & 0.157 & 1.047 \\
\hline $\begin{array}{l}\text { Perkembangan } \\
\text { Intelektual }\end{array}$ & 1.244 & 0.012 & 3.470 & & & 1.320 & 9.124 \\
\hline Kebiasaan & 1.356 & 0.016 & 0.258 & & & 0.085 & 0.777 \\
\hline Pengalaman & 1.061 & 0.032 & 2.889 & & & 1.096 & 7.619 \\
\hline Constant & & & 0.000 & & & & \\
\hline
\end{tabular}

Berdasarkan tabel 4 menunjukkan bahwa variabel independen yang paling besar pengaruhnya terhadap penerapan berpikir kritis perawat dalam melaksanakan asuhan keperawatan pada pasien di RSUD Curup adalah faktor perkembangan intelektual perawat di rumah sakit $\mathrm{p}$ value $0.012(95 \%$ CI 1. $320-9.124)<\mathrm{p} \alpha 0.05$. Di dapatkan Odds Ratio (OR) dari variabel perkembangan intelektual adalah 3.5, artinya perawat yang mempunyai perkembangan intelektualnya baik akan menerapkan berpikir kritis sebesar 3.5 kali lebih tinggi dibandingkan dengan perawat yang tidak memiliki perkembangan intelektual yang kurang baik setelah dikontrol variabel kebiasaan, pengalaman, dan motivasi. Sedangkan nilai koefisien determinasi ( $\mathrm{R}$ square 0.159), hal ini berarti bahwa keempat variabel baik motivasi, perkembangan intelektual, kebiasaan, dan pengalaman dapat menjelaskan variabel penerapan berpikir kritis perawat dalam melaksanakan asuhan keperawatan sebesar $16 \%$ sisanya dijelaskan oleh faktor lain yaitu kecemasan, perasaan, konsistensi dan karakteristik perawat itu sendiri seperti usia, pendidikan, dan jenis kelamin serta budaya.

\section{PEMBAHASAN}

Berdasarkan hasil penelitian analisis faktor yang mempengaruhi penerapan berpikir kritis perawat dalam melaksanakan asuhan keperawatan pada pasien di ruang rawat inap RSUD Curup memberikan gambaran sebagai berikut : 


\section{Karakteristik perawat bekerja di ruang rawat inap yang melaksanakan asuhan keperawatan.}

Hasil penelitian ini menunjukkan bahwa jenis kelamin sebagian besar perempuan (73\%). Hasil penelitian ini menemukan tidak adanya perbedaan kemampuan berpikir kritis antara laki-laki dan perempuan. Tidak ada perbedaan yang signifikan kemampuan berpikir kritis berdasarkan jenis kelamin. Jumlah perawat perempuan di Indonesia sampai saat ini masih memegang peranan yang lebih banyak dibandingkan dengan perawat laki-laki. Hal ini disebabkan oleh latar belakang budaya dan kebangsaan serta sejarah keikutsertaan perawat sebagian besar adalah perawat perempuan yang turut serta dalam mengembangkan kesehatan (Priharjo, 2008). Begitu juga hasil penelitian lainnya disebutkan bahwa proporsi perawat yang cenderung berpikir kritis adalah berjenis kelamin perempuan lebih banyak daripada berjenis kelamin laki-laki (Aprisunadi, 2011). Namun penelitian lainnya menjelaskan bahwa kemampuan berpikir kritis tidak dipengaruhi oleh jenis kelamin, artinya bahwa tidak ada perbedaan dalam berpikir kritis antara laki-laki dan perempuan ( Mulyaningsih ,2013).

Hasil penelitian menunjukkan tingkat pendidikan perawat sebagian besar belum ners (D3/S1 Keperawatan) (77.9\%). Hasil penelitian ini belum bisa membandingkan kemampuan keterampilan berpikir kritis antara pendidikan ners dan pendidikan yang belum ners karena pendidikan yang belum ners jumlahnya lebih banyak ketimbang pendidikan ners. Status perkawinan perawat sebagian besar $(80.5 \%)$ sudah menikah. Dan status kepegawaian sebagian (56.6\%)
Pegawai Negeri Sipil (PNS). Hasil penelitian ini menunjukkan jumlah yang hampir sama.Usia perawat hampir sebagian (47\%) usia produktif.

Menurut Erikson dijelaskan bahwa rentang umur 25-45 tahun merupakan tahap perkembangan generativitas vs stagnasi, pada usia ini dijelaskan dimana seseorang memperhatikan gagasan atau ide - ide, dan keinginan atau dorongan untuk berbagi pengetahuan, serta meningkatkan kreativitas. Lama kerja perawat hampir sebagian (42\%) memiliki lama kerja $\geq 6$ tahun. Menurut Suyanto (2008), seorang perawat apabila sudah bekerja melaksanakan asuhan keperawatan kepada pasien selama $\geq 6$ tahun dengan latar pendidikan D3 atau S1 keperawatan maka perawat tersebut sudah bisa menjadi ketua tim dalam kelompoknya, karena sudah memiliki pengalaman dalam melaksanakan asuhan keperawatan.

\section{Gambaran faktor yang mempengaruhi penerapan berpikir kritis perawat.}

Hasil penelitian ini menunjukkan bahwa gambaran faktor yang mempengaruhi penerapan berpikir kritis perawat di RSUD Curup sebagian besar kurang baik pada faktor kondisi fisik, dan motivasi. Faktor yang sebagian besar baik pada faktor kecemasan, perkembangan intelektual, kebiasaan, konsistensi, dan pengalaman. Sedangkan faktor yang hampir sebagian sama mempengaruhi adalah faktor perasaan.

Menurut Maslow dalam Siti Mariyam (2006:4) Dalam menjalani kehidupan diperlukan kondisi fisik baik. Kondisi fisik merupakan kebutuhan fisiologi paling dasar bagi kebutuhan manusia. Ketika kondisi fisik seseorang terganggu padahal seseorang 
tersebut dihadapkan pada situasi yang menuntut pemikiran matang untuk memecahkan suatu masalah yang dihadapi, maka kondisi seperti ini sangat dapat mempengaruhi pikirannya, sehingga pemecahan masalah tidak dapat diselesaikan dengan baik. Dikatakan juga bahwa motivasi dapat mempengaruhi berpikir kritis seseorang. Motivasi merupakan hasil faktor internal dan eksternal. Motivasi adalah upaya yang dilakukan untuk menimbulkan rangsangan, dorongan ataupun pembangkit tenaga seseorang agar mau berbuat sesuatu atau memperlihatkan perilaku tertentu yang telah direncanakan untuk mencapai tujuan yang telah ditetapkan. Dorongan yang kuat dalam bekerja dapat memberikan semangat seseorang untuk berpikir kritis dalam memecahkan masalahnya. Menciptakan minat adalah cara yang sangat baik untuk memberi motivasi pada diri demi mencapai tujuan (Kort 1987, dalam Zafri, 2012).

\section{Gambaran faktor yang mempengaruhi penerapan berpikir kritis dalam melaksanakan asuhan keperawatan pada pasien di RSUD Curup.}

Hasil penelitian ini menunjukkan penerapan berpikir kritis perawat dalam melaksanakan asuhan keperawatan pada pasien masih memiliki nilai dibawah $60 \%-70 \%$ adalah penerapan perawat dalam melakukan pengkajian, penerapan dalam menentukan diagnosa keperawatan, dan penerapan dalam mengevaluasi asuhan keperawatan. Sedangkan pernerapan berpikir kritis perawat dalam melakukan perencanaan keperawatan dan melakukan tindakan keperawatan memiliki nilai lebih dari $70 \%$. Hal ini tidak sejalan dengan penelitian yang sudah dilakukan di rumah sakit Kepahyang bahwa penerapan berpikir kritis perawat setelah diberikan pelatihan akan meningkatkan pelaksanaan asuhan keperawatan yang lebih baik pada saat melakukan pengkajian dan melakukan implementasi keperawatan.

Faktor yang dapat menyebabkan kurangnya kemampuan perawat berpikir kritis dalam melaksanakan asuhan keperawatan di RSUD Curup menunjukkan pada hasil penelitian sebagian besar kondisi fisik yang kurang baik dan kurangnya motivasi dalam menerapkan berpikir kritis dalam memberikan asuhan keperawatan pada pasien.

\section{Hubungan karakteristik dengan penerapan berpikir kritis dalam melaksanakan asuhan keperawatan asuhan keperawatan.}

Hasil penelitian ini menunjukkan hubungan karakteristik dengan penerapan berpikir kritis perawat dalam melaksanakan asuhan keperawatan tidak ada hubungan antara jenis kelamin, usia, pendidikan, status perkawinan dan status kepegawaian. Sedangkan yang ada hubungan signifikan antara karakteristik dengan penerapan berpikir kritis perawat dalam melaksanakan asuhan keperawatan adalah lama kerja.

Menurut Aprisunadi (2011) dalam penelitiannya tidak menemukan adanya hubungan yang bermakna antara usia dan kualitas dalam memberikan asuhan keperawatan. Hasil penelitian ini tidak sejalan dengan hasil penelitian Feng at all (2010) dimana hasil penelitiannya menunjukkan bahwa faktor pengalaman dan usia secara signifikan adalah faktor yang paling mempengaruhi kemampuan seorang perawat dalam memberikan asuhan keperawatan pada pasien.

Tujuan pembelajaran atau pendidikan kepada orang dewasa adalah lebih mengarah kepada 
pencapaian kemantapan identitas dirinya sendiri untuk menjadi jati dirinya sendiri. Orang dewasa dalam melakukan kegiatan pembelajaran bukan menjadi objek yang dibentuk untuk menyesuaikan dengan keinginan pemegang otoritas, namun untuk dirinya sendiri dalam memberikan pengalaman (Asmin, 2015). Orang dewasa yang mempunyai kisaran umur 25- 45 tahun merupakan umur yang mempunyai tahap perkembangan generativitas vs stagnasi, pada kisaran dalam usia ini baik untuk diberikan pembelajaran dimana pada masa ini seseorang selalu mempunyai gagasan atau selalu memperhatikan ide-ide, dan keinginannya untuk berbagi pengetahuan, dan selalu ingin meningkatkan kreativitas.

Hasil penelitian ini sejalan dengan teori Swanburg (1999) dijelaskan bahwa jika masa kerja seseorang bertambah maka akan semakin bertambah pula pengalaman kliniknya. Dapat dikatakan bahwa pengalaman dan masa kerja saling terkait. Maka semakin bertambah masa kerja seseorang maka akan semakin bertambah pula pengalaman klinik dan keterampilan klinisnya. Hal ini memberikan pengalaman pada seseorang mengasah kemampuan berpikir kritis secara rutin dalam melaksanakan pekerjaannya.

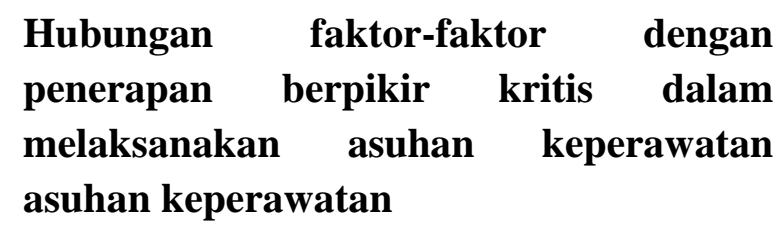

Hasil penelitian hubungan faktor-faktor dengan penerapan berpikir kritis dalam melaksanakan asuhan keperawatan adalah ada hubungan yang bermakna antara faktor motivasi, faktor kecemasan, faktor perkembangan intelektual dan faktor pengalaman dengan penerapan berpikir kritis dalam melaksanakan asuhan keperawatan. Sedangkan faktor yang tidak ada hubungan yang signifikan adalah faktor kondisi fisik, faktor perasaan, faktor kebiasaan, dan faktor konsistensi dengan penerapan berpikir kritis perawat dalam melaksanakan asuhan keperawatan.

Hasil penelitian ini sejalan dengan penelitian Aprisunadi (2011) ada hubungan antara berpikir kritis dengan kualitas asuhan keperawatan. Namun yang berkontribusi bermakna adalah pengalaman praktik (p.0.012) adanya hubungan yang signifikan berpikir kritis dengan kualitas asuhan keperawatan.

Pertambahan masa kerja seseorang semakin akan memberikan pertambahan pengalaman dan keterampilan klinisnya. Lebih lanjut dijelaskan bahwa semakin banyaknya pengalaman praktik yang dimiliki oleh perawat maka perawat tersebut dapat meningkatkan kemampuannya dalam berpikir kritis, iniakan sangat membantu dalam menghadapi kendala kerja yang dihadapinya dengan memberikan respon cepat dan tanggap, bahkan pengalaman ini dapat mengasah kemampuan berpikir kritis dalam bekerja. Dijelaskan oleh Roche (2008) bahwa pengalaman praktik yang pernah dilakukan akan menambah pengalaman belajar klinis dan dapat menambah kemampuan dalam berpikir kritis, hal ini sangat diperlukan untuk memenuhi keterampilan dalam membuat keputusan. Sedangkan menurut Marta (2002) dijelaskan bahwa keterpaparan dengan masalah klinik di lahan praktik keperawatan dapat memberikan kesempatan kepada perawat untuk membiasakan menerapkan keterampilannya, sehingga berpikir kritis terbiasa rutin 
dilakukan. Namun jika seseorang yang mengabaikan kemampuan berpikir kritisnya maka akan semakin menumpulkan keterampilannya.

\section{Faktor dominan mempengaruhi penerapan berpikir kritis dalam melaksanakan asuhan keperawatan pada pasien di RSUD Curup.}

Faktor karakteristik yang paling dominan pengaruhnya terhadap penerapan berpikir kritis perawat dalam melaksanakan asuhan keperawatan pada pasien di RSUD Curup adalah lama kerja perawat di rumah sakit. Perawat yang bekerja sebagai perawat lebih dari atau sama dengan 6 tahun akan menerapkan berpikir kritis sebesar 0.05 kali dibandingkan dengan perawat yang bekerja sebagai perawat dengan lama kerja kurang dari 6 tahun setelah dikontrol variabel jenis kelamin dan usia. Kemampuan berpikir kritis perawat dalam melaksanakan asuhan keperawatan sangat dipengaruhi oleh sifatsifat psikologis dan fisiologis serta lingkungan seperti usia seseorang, tingkat kepercayaan memecahkan masalah, keterampilan yang dimiliki, tingkat stress, dan kondisi kelelahan, serta keberadaan rekan kerja (Sumartini, 2010). Hasil penelitian ini lama kerja perawat di rumah sakit dalam melaksanakan asuhan keperawatan pada pasien sebagian besarlebih dari 6 tahun, hal ini dapat memberikan pengalaman dalam pelaksanaan praktik keperawatan. Sejalan dengan teori Swanburg (1999) pengalaman masa kerja seseorang akan menambah pengalaman klinik dan meningkatkan keterampilan klinisnya sehingga kemampuan berpikir kritispun akan semakin terbiasa.

Faktor lain selain karakteristik perawat yang mempunyai paling dominan pengaruhnya terhadap penerapan berpikir kritis perawat dalam melaksanakan asuhan keperawatan pada pasien di RSUD Curup adalah faktor perkembangan intelektual perawat. Perkembangan intelektual mempunyai nilai OR 3.5, artinya perawat yang mempunyai perkembangan intelektualnya baik akan menerapkan berpikir kritis sebesar 3.5 kali lebih tinggi dibandingkan dengan perawat yang kurang baik memiliki perkembangan intelektual setelah dikontrol variabel kebiasaan, pengalaman, dan motivasi.

Penelitian ini tidak sejalan dengan penelitian yang dilakukan oleh feng et al (2010), dikatakan bahwa lama pengalaman praktik di klinik, tingkatan pendidikan dan umur merupakan faktor - faktor yang dapat mempengaruhi kompetensi dan kecenderungan berpikir kritis perawat. Namun hasil penelitian yang sejalan dengan Feng et al. (2010) adalah menyatakan bahwa faktor pengalaman dari rumah sakit lain secara signifikan dapat mempengaruhi kompetensi berpikir kritis perawat $(\mathrm{p}<0.05)$.Perbedaannya disini adalah faktor pengalaman yang didapatkan Feng et all didapatkan dari rumah sakit lain sedangkan pengalaman yang didapatkan peneliti adalah pengalaman dengan lamanya bekerja di rumah sakit itu sendiri.

Perkembangan intelektual perawat di RSUD Curup, saat ini perawat perawat profesional sudah mencapai $21 \%$. Hal ini dapat memberikan kontribusi peningkatan berpikir kritis perawat dalam melaksanakan asuhan keperawatan. Perkembangan intelektual dapat meningkatkan intelegensi perawat. Pengertian intelegensi adalah sebagai suatu kemampuan individu untuk belajar dan berfikir abstrak yang berguna untuk menyesuaikan diri secara mental dalam situasi baru. Intelegensi juga merupakan 
salah satu dari faktor yang mempengaruhi hasil proses pembelajaan. Intelegensi bagi seseorang merupakan salah satu modal yang dapat digunakan untuk berfikir dan mengolah berbagai informasi secara sistematis dan terarah sehingga mempunyai kemampuan dalam menguasai lingkungan.(Khayan, 1997).

Faktor dari perkembangan intelektual perawat dapat mempengaruhi penerapan berpikir kritis perawat dalam melaksanakan asuhan keperawatan setelah dikontrol oleh kebiasaan, pengalaman, dan motivasi. Penelitian ini tidak sejalan dengan penelitian Mulyaningsih (2013), yang menjelaskan bahwa ada hubungan yang signifikan antara berpikir kritis dengan perilaku caring perawat dalam melaksanakan asuhan keperawatan. Dilanjutkan dengan hasil penelitian yang lain menjelaskan bahwa salah satu faktor yang dapat memberikan penurunan kemampuan berpikir kritis seseorang apabila seseorang sudah terjebak ke dalam rutinitas pekerjaan, dan rutinitas yang secara terus menerus dilakukan menjadikan kebiasaan yang sulit untuk dirubah (Rubenfeld \& Scheffer, 2007).

Kebiasaan yang dimaksud dalam penelitian ini adalah kebiasaan perawat dalam memberikan pelayanan dan mendokumentasikan asuhan keperawatan. Kebiasan yang kurang patuh terhadap standar pelayanan akan menurunkan berpikir kritis perawat dalam melaksanakan asuhan keperawatan.

Pengalaman merupakan hal utama untuk berpindah dari seorang pemula menjadi seorang ahli, pengalaman perawat di RSUD Curup adalah ditunjang dengan masa kerja yang lama dan $27 \%$ sebagai perawat yang tadinya vokasional berpengalaman meningkat menjadi perawat professional.

Peningkatan jenjang perawat vokasional menjadi professional dipengaruhi oleh faktor motivasi. Motivasi dalam meningkatkan kemampuan dipengaruhi oleh faktor internal dan eksternal (lingkungan yang menumbuhkan keinginan untuk berubah) Motivasi merupakan upaya untuk menimbulkan rangsangan, dorongan ataupun pembangkit tenaga untuk melaksanakan sesuatu tujuan yang telah ditetapkannya (Lewin, 1935 dalam Maryam, Setiawati \& Ekasari, 2007). Motivasi yang dilakukan perawat RSUD Curup dalam meningkatkan pengetahuannya sebagai sebagai pemicu melakukan pergerakan positif untuk mencapai tujuan dalam penerapan berpikir kritis asuhan keperawatan adalah 1) akibat pengalaman yang kurang menyenangkan membuat dorongan dari dalam dirinya untuk melakukan tindakan atau pelayanan yang lebih baik, 2) akibat seringnya memberikan tindakan/ pelayanan tersebut sehingga kemampuannya bertambah, 3) akibat ketidakpedulian terhadap pelayanan kemudian di tegur / diingatkan oleh teman sejawat, membuat kesadaran diri untuk melakukan asuhan keperawatan yang lebih baik.

\section{KESIMPULAN}

Faktor yang mempengaruhi mempengaruhi penerapan berpikir kritis perawat di Rumah Sakit Umum Daerah Curup adalah lama masa kerja, motivasi, perkembangan intelektual, kebiasaan dan pengalaman perawat dalam melaksanakan asuhan keperawatan kepada pasien. Perkembangan intelektual perawat dapat meningkatkan berpikir kritis yang paling dominan dalam melaksanakan asuhan 
keperawatan. Perkembangan intelektual perawatan didapatkan dengan cara pendidikan formal maupun informal seperti pelatihan kompetensi berpikir kritis dalam melaksanakan asuhan keperawatan.

\section{DAFTAR PUSTAKA}

American Society of registered nurses. (2007). Critical thinking and evidence-based nursing. Diunduh dari http://www.asrn.org.

Aprisunadi. (2011). Hubungan antara berpikir kritis perawat dengan kualitas asuhan keperawatan di unit perawatan ortopedi rumah salkit umum pusat fatmawati Jakarta: Universitas Indonesia.

Feng at., all. (2010). Critical thinking competence and disposition of clinical nurse in a medical center. Journal of Nursing Rearch, 18(2), 77-8.

Halpern, D. F. (1996). Thinking critically about critical thinking. USA: L. Erlbaum Associates, Orginal Text from University of California.

Kaddoura, M. A. (2010). Effect of the essentials of critical care orientation (ECCO) program on the development of nurses' critical thinking skills. Journal of Conditioning Education in Nursing, 41(9), 424-432.

Leininger, M. (2002). Culture care theory: A major contribution to advance transcultural nursing knowledge and practices Journal of Transcultural Nursing, 13:189.

Maryam, R., Setiawati, S., \& Ekasari M. F. (2007). Buku ajar berfikir kritis dalam proses keperawatan. (cetakan 1). Jakarta: EGC.

Mulyaningsih. (2013). Peningkatan perilaku caring melalui kemampuan berpikir kritis perawat. Jurnal Manajemen Keperawatan, I(2), 100-106.
Priharjo, R. (2008). Konsep \& perspektif praktik keperawatan profesional.(Edisi 2). Jakarta: EGC.

Roche, J. P. A. (2000). Pilot study of clinical decision making making with the clinical educator model. Journal of Nursing Education, 41(8), 365-367.

Rubenfeld, M. G., \& Scheffer, B. K. (2007). Berpikir kritis dalam keperawatan. (A. Lusiyana, N. Herdina, D.Yulianti, Penerjemah). Jakarta: EGC.

Sumartini, B.T. (2010). Pengaruh penerapan panduan coaching kepala ruang terhadap kemampuan berpikir kritis dan pengambilan keputusan perawat primer dalam proses keperawatan di ruang rawat inap PKSC. Tesis FIK UI. Tidak dipublikasikan.

Suyanto. (2008). Mengenal kepemimpinan dan manajemen keperawatan. Jogjakarta: Mitra \& Cendikia Press.

Swanburg. R.C. \& Swanburg, R. J. (1999). Introductory management and leadership for nurses. An introductive text. $2 r d$ Ed. Sudbury Massachusetts: Swanburg RC \& Jhon and Burlett Publisher

Zafri. (2012). Berfikir kritis pembelajaran sejarah. Jurnal Diakronika FIS UNP di unduh tanggal 12 Agustus 2017. 